\title{
Withdrawn: Effect of routing paradigm on patient- centered outcomes in acute ischemic stroke
}

Zhou MH, Kansagra AP. Effect of routing paradigm on patient-centered outcomes in acute ischemic stroke. J NeuroIntervent Surg 2018:doi: 10.1136/neurintsurg-2018-013994 [Epub ahead of print $03 \mathrm{Jul} 2018$ ].

This article has been withdrawn from the Journal of NeuroInterventional Surgery. The editorial office has received an email from Dr Akash Kansagra, one of the authors, detailing multiple corrections in their data specifically pertaining to errors of over-representation in their simulation analysis. Although the authors have stated that these data errors do not alter the conclusions of their manuscript, the editorial board has withdrawn this paper and asked the authors to address these errors in a revision that would be subject to further peer review.

(C) Author(s) (or their employer(s)) 2018. No commercial re-use. See rights and permissions. Published by BMJ.

J Neurolntervent Surg 2018;0:1. doi:10.1136/neurintsurg-2018-013994.wit

D) Check for updates 